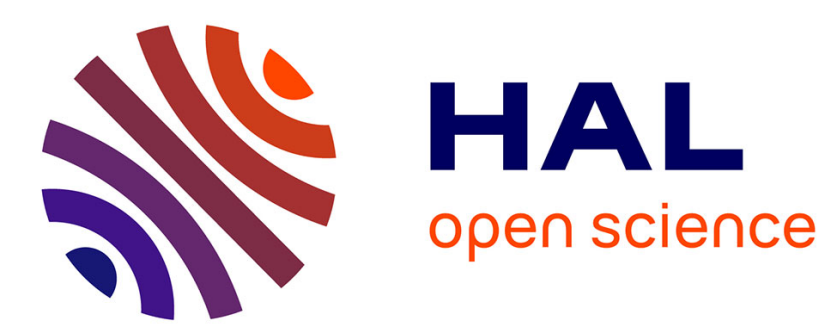

\title{
Innovative bioguided fractionation of cranberry juice for Candida biofilm treatment and infected-wound healing
}

Leslie Boudesocque-Delaye, T. Puy, Marion Girardot, Arnaud Lanoue, Laurent Bazinet, Charles Bodet, Christine Imbert, Cécile Enguehard-Gueiffier

\section{- To cite this version:}

Leslie Boudesocque-Delaye, T. Puy, Marion Girardot, Arnaud Lanoue, Laurent Bazinet, et al.. Innovative bioguided fractionation of cranberry juice for Candida biofilm treatment and infected-wound healing. 7. International Conference on Polyphenols and Health, Oct 2015, Tours, France. , 2015. hal-01256486

\author{
HAL Id: hal-01256486 \\ https://hal.science/hal-01256486
}

Submitted on 3 Jun 2020

HAL is a multi-disciplinary open access archive for the deposit and dissemination of scientific research documents, whether they are published or not. The documents may come from teaching and research institutions in France or abroad, or from public or private research centers.
L'archive ouverte pluridisciplinaire HAL, est destinée au dépôt et à la diffusion de documents scientifiques de niveau recherche, publiés ou non, émanant des établissements d'enseignement et de recherche français ou étrangers, des laboratoires publics ou privés. 


\section{P817}

\section{Innovative bioguided fractionation of cranberry juice for Candida biofilm treatment and infected- wound healing.}

L. Boudesocque-Delaye,,${ }^{1, *}$ T. Puy, ${ }^{2}$ M. Girardot, ${ }^{2}$ A. Lanoue,${ }^{3}$ L. Bazinet,${ }^{4}$ C. Bodet,${ }^{5}$ C. Imbert, ${ }^{2}$ C. Enguehard-Gueiffier 6

$I^{*}$ Université de Tours, UMR INRA 1282 ISP, 31avenue Monge, 37200 Tours, France, Ieslie.boudesocque@univ-tours.fr

2 Université de Poitiers, UMR-CNRS 7267 - EBI, Bât. D1, 6 rue de la Milétrie, TSA 5111586073 Poitiers Cedex 9, France

3 Université de Tours, EA 2106 BBV, 31 avenue Monge, 37200 Tours, France

4 Institut sur la Nutrition et les Aliments Fonctionnels (INAF), Département de sciences des Aliments, Université Laval, 2425 Rue de I'agriculture, Québec, QC, GIVOA6, Canada

5 Université de Poitiers, A 4331 LITEC, Pole Biologie Santé, 1 rue Georges BonneTSA 51106, 86073 Poitiers Cedex 9, France 6 Université de Tours, INSERM U1069 N2C. 31 avenue Monge, 37200 Tours, Franc

Cranberry polyphenols are intensively studied for their anti-infectious and antioxidant properties. Nevertheless, in biofilm and infected-wound healing, the identity of active polyphenols still remains unclear. In order to identify active polyphenols, an innovative fractionation scheme based on Centrifugal Partition Chromatography (CPC) was developed. CPC is a support free liquid/liquid chromatographic technology used here for the first time to fractionate cranberry juice. The fractionation protocol involved 3 mains steps: firstly polyphenol and sugars separation; then polyphenols fractionation based of molecular weight and polarity, and finally CPC or on LH-20 resin.

Following the second step, the 6 main fractions obtained were screened on Candida biofilm and toward infected wound. Fractions containing low molecular weight proanthocyanidins (Fr III and IV) and containing high molecular weight PAC (Fr V ad VI) exhibited the most interesting activities. Concerning Candida albicans biofilm a prophylactic effect was observed by prevention of adhesion. On infected wound, a wound-healing potential related to anti-inflammatory effect but not to antibacterial activity against Staphylococcus aureus was highlighted.

These four active fractions were further purified using either CPC or LH-20 resin, to lead to almost 40 sub-fractions. Again fractions containing PACs of medium and high molecular weight exhibited the highest activity against adhesion step of $\mathrm{C}$. albicans strains and infected wound healing.

This work is a step further to understand mechanisms of action of cranberry polyphenols on $C$. albicans biofilm prevention and in infected wound healing.

Financial support: ARC Tours Poitiers 2014 grant, FERI Région Centre 2013 grant

\section{P818}

\section{Chemical fingerprints and biochemical activities of edible congolese hibiscus leaves}

P. Mutwale ${ }^{1,2^{*}}$, N. Ngombe ${ }^{2}$, C. Tsumbu ${ }^{1}$, T. Franck ${ }^{3}$, A. Mouithys-Mickalad ${ }^{3}$, D. Mumba ${ }^{4,5}$, D. Tshala-Katumbay ${ }^{4,6}$, P. Kalenda ${ }^{2}$, D. Serteyn ${ }^{3}$, M. Tits ${ }^{1}$, M. Frédérich

${ }^{1}$ Laboratory of Pharmacognosy, Center for Interdisciplinary Research on Medicines (CIRM), University of Liège, CHU, B-4000

Liège 1, Belgium

${ }^{2}$ Centre d'Etudes des Substances Naturelles d'Origine Végétale (CESNOV), Faculty of Pharmaceutical Sciences, University of Kinshasa, Kinshasa, BP 212 Kin XI, Democratic Republic of Congo

${ }^{3}$ Centre for Oxygen Research and Development (C.O.R.D.), Institute of ChemistryB6a, University of Liège, B- 4000 Liège, Belgium

${ }^{4}$ Faculty of Medicine, University of Kinshasa, Kinshasa, BP 834 Kin XI, Democratic Republic of Congo

${ }^{5}$ Institut National de Recherches Biomédicales (INRB), Kinshasa, BP1197Kin-Gombe, Democratic Republic of Congo

${ }^{6}$ Department of Neurology, Oregon Health \& Science University, Portland, OR97239, USA

Hibiscus acetosella, Hibiscus cannabinus and Hibiscus sabdariffa leaves are widely consumed as vegetables in the form of sauces by Congolese people (Democratic Republic of Congo).

The aim of this study was to compare the chemical fingerprints and the correlations between anti-inflammatory (myeloperoxidase (MPO) activity) and antioxidant properties of polar and non polar extracts of these plants. Antioxidant properties were evaluated by using 2',7'-dichlorofluorescein-diacetate (DCFH-DA) and lucigenin on neutrophils and HL-60 cells. Chemical fingerprints were performed by Thin Layer Chromatography and High Performance Liquid Chromatography.

Chemical fingerprintings revealed that $H$. acetosella has a fingerprint different to $H$. cannabinus and $H$. sabdariffa that have the same fingerprint. Major compounds are phenolic acids represented by caffeoyhydroxicitric acid for $\mathrm{H}$. acetosella and neochlorogenic acid for the others. All extracts displayed high ABTS and DPPH radical-scavenging activities at the concentration range of $10-80 \mu \mathrm{g} \mathrm{mL}^{-1}$ and antioxidant activity assays at $0.05-10 \mu \mathrm{g} \mathrm{mL}^{-1}$, according to the following order: H.acetosella $>$ H.cannabinus $>$ H.sabdariffa. Non polar extracts exhibited a strongest superoxide 


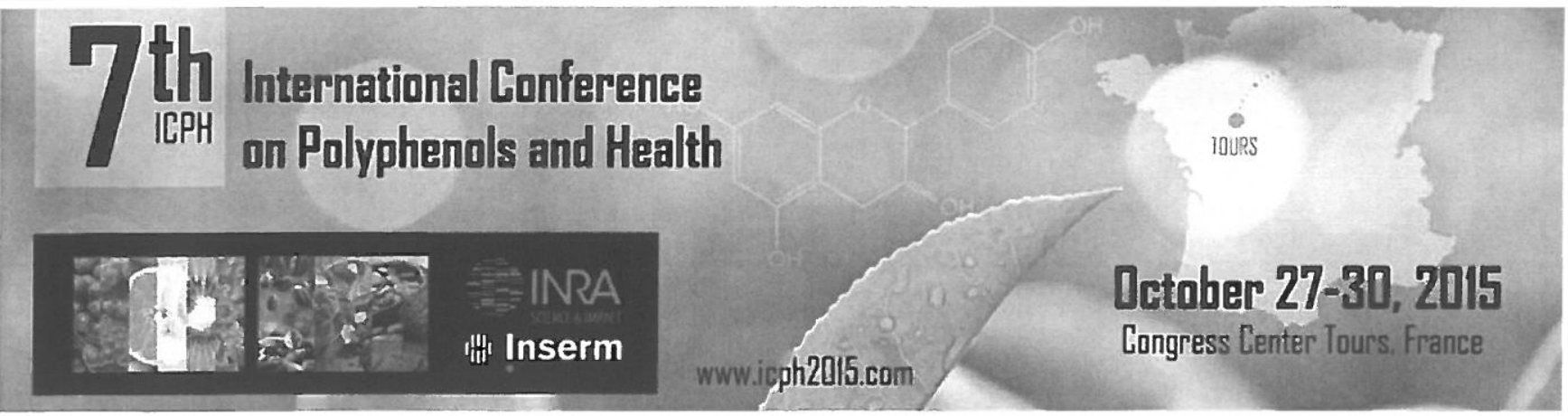

\section{CONTENTS}

Welcoming message

Committees

Program at a glance

Conference center plan

Scientific program

Guidelines for scientific communications

Social program

General information

Sponsors

Invited speaker biographies

Abstracts

Invited lectures

Selected communications

Posters

A: Polyphenol bioavailability and exposure assessment.

B: Polyphenols in obesity, metabolic syndrome and diabetes.

C: Neuro-cognitive effects of polyphenols

D: Polyphenols and cancer prevention

E: Polyphenols in cardiovascular diseases

F: Innovative approaches in polyphenol research................................... 201

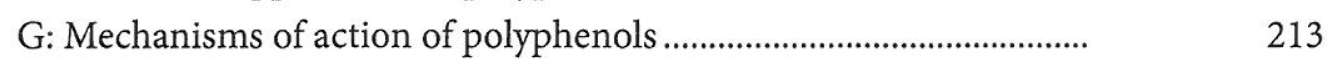

$\mathrm{H}$ : Polyphenols and gut Microbiota interactions .................................. 235

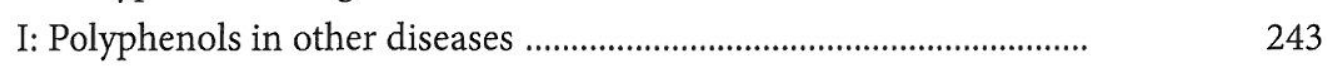

J: Polyphenols and Food Processing ............................................................. 261

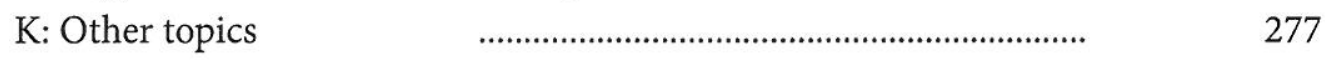

Authors index 